\title{
Language, Communication, and Law: Dismantling Binary Opposition in the Pre-Adjudication Sphere
}

\author{
Rocky Marbun ${ }^{1}$, Endra Wijaya ${ }^{2}$ \\ \{rocky_marbun@univpancasila.ac.id ${ }^{1}$, endra.wijaya333@yahoo.co.id ${ }^{2}$ \} \\ 1,2 Faculty of Law, University of Pancasila, Jakarta-Indonesia,
}

\begin{abstract}
Language is a 'big house' for every science, there is no single science that does not use language as an intermediary instrument including Law. Language in the field of law is used no more than a way to formulate laws and track fallacies. On the other hand, the language in the form of speech as a form of communication has never been seriously studied in the Law. This study focuses on language models of speech in verbal communication conducted by Investigators/Prosecutors with the public. The method used in this study is normative juridical based on secondary data in the form of primary legal materials, secondary legal materials, and tertiary legal materials obtained based on library research. Based on the normative juridical research method, we use several approaches, namely philosophical approaches, conceptual approaches, language approaches, participatory approaches, and case approaches. Based on this, spoken language in verbal communication has a psychological impact on ordinary people who intersect with the law in the context of practice. This study propose several changes in Indonesian criminal procedural law.
\end{abstract}

Keywords. Language, Communication, Law, Criminal, Investigator/Public Prosecutor

\section{Introduction}

Language skills for each Bachelor of Law, especially written language, become an inexorable ability. However, the Faculty of Law curriculum only contains two (2) Indonesian language courses, namely Indonesian and Indonesian Legal Language. The two courses focused more on the ability of students to be able to write based on grammatical structures and the ability to trace the truth of logic in the written language which led to the ability to write scientific work and the ability to write for practical purposes.

This became in line with the accommodation of civil law as an official legal system in Indonesia. The pressure point in the civil law legal system is the use of written legal rules. This system developed in mainland Europe, spread on mainland Europe and its colonies (Praja, 2011). Thus, all legal proceedings in Indonesia are always based on written administrative behavior. One example is Article 117 paragraph (2) of the Criminal Procedure Code which confirms "If the suspect gives information about what he has done in connection with the criminal offense against him, the investigator records in the minutes as thoroughly as possible according to the word used by the suspect himself." Or for example in Article 103 paragraph (1) of the Criminal Procedure Code which confirms "Reports or complaints submitted in writing must be signed by the reporter or complainant." Or another example is Article 182 paragraph (1) letter c KUHAP which confirms "Claims, defense, and answers to 
the argument are carried out in writing, and after they are read, they are immediately submitted to the presiding judge and their derivatives to interested parties."

Based on the authoritative text above, it is as if the law is running on its tracks when a Law Enforcement Officer -including Advocates, is able to pour well and correctly in the form of written language based on clear rules, when it is understood that written language is actually no more an externalization and a combination of thoughts, knowledge, and interests of Law Enforcement Officials itself.

This research becomes essential when, for Law Scholars, both academics and practitioners, in general, see the problem of language as something that is marginalized in every scientific study of Law. This study also narrows the scope only at the pre-adjudication stage, namely investigation and prosecution, does not enter the view of the examination process before the trial (adjudication stage). Why is the importance of this research limited in scope? Therefore, at the pre-adjudication stage, there is an imbalance of the original position between the party checking and the party being examined. You might be able to refute our argument, by submitting the existence of an Advocate to the examination process. However, in the criminal justice system adhered to by the Criminal Procedure Code, it has limited Advocates to be passive and if acting actively will result in the expulsion of the Advocate from the inspection process.

We reveal the imbalance of the original position based on a study conducted by Erik Saut H. Hutahaean (2015) who collaborated on several studies where for example according to De Camargo (2012), the use of uniforms and the police profession can usually give contamination to life. Namely, contamination gets ownership of personal circumstances, in the form of ownership of specific status titles. As also described by Herzog (2001), that the appearance of the police explains the owner of the professional police goals. That is to fight against evil and also provide services. Therefore many events were found in the community, which showed an increase in certain psychological conditions in people wearing police uniforms. Both the actual police and civilians are wearing police uniforms for specific purposes. As for relating to the level of "rank" describes the scale and position of all members in the police structure. Rank levels are sometimes associated with psychological conditions in managing work. From the results of an investigation study conducted by Sidanius, Liu, Shaw, and Pratto (1994) it can be seen that ranks in the police field are often controlled by views related to social domination. Likewise with the attribute of "firearms". "Firearms" (firehand/handgun) is one of the supporting tools used to carry out security tasks. In the process of using it, a series of psychological examinations are needed. This is often associated with mental conditions that can affect the behavior of its use. Diuguid (2014) explains that possession of guns provides people with a sense of strength and security control, but on the other hand, also shapes fear and concerns about the impact that can hurt others. In an overview of technical reports (1996 technical report) about psychological evaluation and control of weapons. It is written that firearms have an individual psychological impact because they are often associated with their use, which can injure or eliminate the lives of others, and also hurt or eliminate their own lives.

If written language is an externalization of the owner of the will, then the imbalance of the original position is manifested in the form of verbal communication or speech acts. What we mean by verbal communication is a model of conversation between the examiner and the examinee before it is poured into the Minutes of Examination or other written documents. The conversational model that appears in the examination process at the investigation level undergoes a communication transformation in the prosecution process by the Public 
Prosecutor that is linked to the model of the Indictment that is determined based on its authority.

At the level of investigation, for example in a study conducted by Robby Satria (2016) which in his research, explained that the suppression of witnesses by communication that is threatening, is one aspect that can be examined through forensic linguistics. Similarly, a study conducted by Ika Arifianti (2016) through the concept of pragmatics explains the existence of a demanding function and an essential function in the arrangement of questions contained in the Minutes of Examination. Concerning urgent functions, manifested in the form of speech acts that lead. As stated by HTP Advocates (May 21, 2019) in the interview filling out the questionnaire was saying that in making the Minutes of Examination (BAP) often entrap in asking questions. In another communication model, for example, what was stated by the ERH Advocate (April 15, 2019) describes the inspection process that Investigators raise questions that appear to be independent or impartial and often act like a Judge who convicts a suspect. In fact, according to the ERH Advocate, Investigators seem not to have received all the information given by the Suspect.

In another model, the behavior of speech acts is also brought about by changes in facial expressions, elevated intonation of sounds, and the emergence of negative emotions - namely anger, from the Investigator, as stated by Advocate H (April 15, 2019) in filling out written interviews. Investigators in carrying out their authority often interpret their authority as a power, so that the control of the meaning of a criminal event occurs. This can be seen in the written chronology dated April 9, 2019, made by JEK - which was examined as a Witness, and JJ - who was investigated as a suspect, in a case based on the Police Report No.: LP / 476/280SPKT / K / VI / 2018 / BKS Restro dated June 7, 2018 and Police Report No.: LP / 1044/648SPKT / K / XI / 2018 / Restro BKS dated November 28, 2018, where the alleged criminal offense to $\mathrm{JJ}$ has reached a bright spot, then $\mathrm{JJ}$ requested that a confrontation be held with the Reporting Party. However, Investigators always promised and stalled for time, until finally JJ's decision was issued as a suspect.

The questions in the Minutes of Examination that have these primary functions and objectives, concerning written language are certainly not a crucial problem. However, when the written language intersects with behavior in speech acts, it becomes a different matter. Therefore, saying a specific utterance can be seen as an action, such as telling, ordering, and influencing. In the event of language, speakers and speaker partners will look to who is speaking, where the conversation is, about the problem being discussed, and the situations and conditions at which the speech takes place. In other words, the context greatly influences the discourse (Hestiyana, 2017).

Referring to the study conducted by Emmanuel Jeuland and Anastasia Sotiropoulou (2012), it was explained that communication factors could also influence the implementation or realization of procedural or procedural principles from a court, especially one of them in the aspect of impartiality or impartiality. So, for those of us who have a scientific basis in the field of Law, it is also vital to examine in more depth the communication models that occur in criminal justice practices in Indonesia, especially in the process of investigation or preadjudication. Based on the descriptions above, it should be questioned about "What is the system of examination in criminal cases in the pre-adjudication domain stipulated in the Criminal Procedure Code?" 


\section{Method}

This research is one model of legal research that takes one aspect of criminal justice practice, which is still very minimal in the field of Law, namely language. As a legal study, it usually uses normative juridical research methods. Legal research with a normative juridical method, in general, uses secondary data in the form of primary legal material consisting of legislation, secondary legal material consisting of court decisions and research results with similar themes, and tertiary legal material consisting of dictionaries and encyclopedia. Research in Law uses a normative juridical method using secondary data through library research (Soekanto \& Mamudji, 1986). However, the superiority of the normative juridical method, we can use several models of research approaches, which include philosophical approaches, conceptual approaches, case approaches, language approaches, and participatory approaches and also critical approaches.

Of course, We understand that research in the scope of linguistics is an empirical study based on primary data. Such a research model, of course, is complicated to find empirical data using primary data. Therefore, according to Raymond Geuss (2004), this will be verbally denied. Why is that? Because according to Raymond Geuss, these things enter unconsciously into them. Nevertheless, we continue to do several written interviews with 8 (eight) Advocates from the Makassar-Gorontalo-Jakarta area and fill out questionnaires by utilizing the Google Form application which is filled by 14 (fourteen) Advocates, and written recognition from 2 (two) people who are currently Witnesses and Suspects/Defendants.

\section{Results and Discussion}

The practice of criminal justice in Indonesia is often interpreted as a process of examination that takes place only in the courtroom alone. Where stated by Sudikno Mertokusumo (2011) himself in interpreting the word "judiciary" by explaining that the judiciary is anything related to the duty of the judge in deciding cases, both civil and criminal cases, to maintain or guarantee the obedience of material law. However, according to Us, it means more to the word "judicial" as widely as possible, namely an activity process of each component and sub-component involved in it starting from the investigation process, investigation before the hearing, deciding the case, and the execution of the verdict or execution. Therefore, in seeking justice, not only in the trial alone but starting from the investigation process, there has been a demand for value to provide a sense of justice for all parties. So that the principle of justice does not belong to the victim or the injured party, but there is also a portion of justice for people who are "suspected" of committing criminal acts. Our view is based on the opinion of Roeslan Saleh (1983), who explained that the court session was only one that perfected what had begun in the preliminary examination (preadjudication).

Judiciary as a system has been constructed based on a combination of functions of law enforcement officers - which in the study of the Criminal Justice System is known as the 'component', which consists of advocates, public prosecutors, judges, and prisons. The division of these components is just assumed to be the right thing. In this system of presuppositions, marginalized binary opposition will emerge namely victims and suspects. Thus, in the practice of criminal justice, two types of binary opposition are created, namely law enforcement-suspects and power-authority. More broadly, the binary opposition emerged 
with the adoption of the Indonesian civil law legal system, namely written language, and oral communication (speech acts); this is the focus of this research.

In binary opposition, one element is privileged, while other elements are marginalized. These two elements are also arranged based on certain boundaries, which make the two elements separate (Ungkang, 2013). Binary Opposition is the core of the system of difference, which is the basis of structural thinking. Binary opposition is always the basis of western philosophy. For example, the word "marker" will be neo-biased with the word "marker", the word "correct" isoposized by the word "wrong" (true/false), the word "male" isoposized by "female" (male/female)

This opposition in linguistics goes hand in hand with the same thing in the western philosophical tradition. In this binary opposition, according to the western philosophical tradition, the terms of the first employer are superior to the second subordinate/employee. The second terms are false representations of the first or inferior. This tradition is called logocentrism and is used to explain the assumption of the privileges that the first term carries and "harassment" against the second term (Norris, 2016).

According to McQuillan, the binary opposition must be reversed, and then it is shown that the whole meaning of the text has been dictated by the binary opposition. By changing the opposition, a balance will be created, but that is not enough without going through the next stage. So, in the second stage, the whole system of thought dictated by binary opposition must be removed, so that the terms in the binary opposition are considered without binary thinking anymore. Without stopping binary thinking, reading will only be trapped in other binary logic. In this process, it will show that the poles in the opposition cannot be kept pure and consistent. The two poles will tarnish one another, namely deconstructing themselves (F. Budi Hardiman, 2015).

When in Derrida's deconstruction, the aim is to uncover binary opposition in displaying and pointing out inferior elements in binary opposition as something that should be heard. So, in this study, We followed Derrida's footsteps to dismantle the subordinate components which were not revealed in the track record of written and ethical rules, as the most decisive position in creating legal actions and actions from a Police Investigator. However, according to Anthon F. Susanto (2010), the aim of reversing the binary opposition is not to break the dominant meaning and turn off pure meaning, but to raise the meaning of being marginalized. Because the illusion of truth arises when one meaning with another meaning hegemony with each other, through different meanings, the essence of the text can be revealed and revealed itself.

To track the binary hierarchical opposition, our understanding indeed starts from the research conducted by De Camargo (2012) relating to uniforms and professions concerning social status, then study by Herzog (2001) which reveals suit and rank with psychological relationships of the police who carry out their duties. Both of these studies were preceded by research conducted by Sidanius, Liu, Shaw, and Pratto (1994) and a Technical Report (technical report 1996) relating to the impact of weapons use and finally by Diuguid (2014) who conducted a study of the relationship between the use of weapons and their influence or psychological effects on the user who often influences his behavior patterns. However, on the other hand, the established communication is a natural thing, because language is synonymous with communication and has a crucial role (Shanty, 2016). Thus, in legal practice, position domination occurs concerning the use of language as a communication tool between Investigators and the examinee. This dominance also arises because of the dominance of power over authority.

Controlling the meaning of the Investigator, consciously, is a process that is applied based on the official guidelines of the investigation. Thus, the verbal communication model 
becomes a tool or instrument to fulfill the objectives of the compilation of questions that are not free of interests. The situation in the instrumental interrogation model arises from the technique taught by the International Criminal Investigative Training Assistance Program (ICITAP) which emphasizes the aspect of self-awareness of the Examiner who is in the masters of the questioner, and the questioner controls even the conversational model. Control of this communication model is a reference for making the Checker as a source of information (Waljinah, 2016).

Such a communication model, if examined through a critical approach, is a retained tradition that departs from an understanding that knowledge is related to power. The tradition assumes that science cannot exist without ideology. Those who have the power to form knowledge in the sense that their work is to maintain existing conditions (status quo). Thus, people who have power try to keep them in control, including silencing the voices of minorities who question the distribution of power and truth in the version of the authorities (Richard West and Lynn H. Turner, 2008).

Based on online questioner through Google Form against several Advocates, when asked the question "how is the Examiner asking questions?", By submitting 3 (three) question options, the results obtained (1) cornering (14.3\%); (2) declare distrust of the information examined; and (3) herding the Checker to answer as the Inspector wishes (71.4\%), as shown in the following diagram:

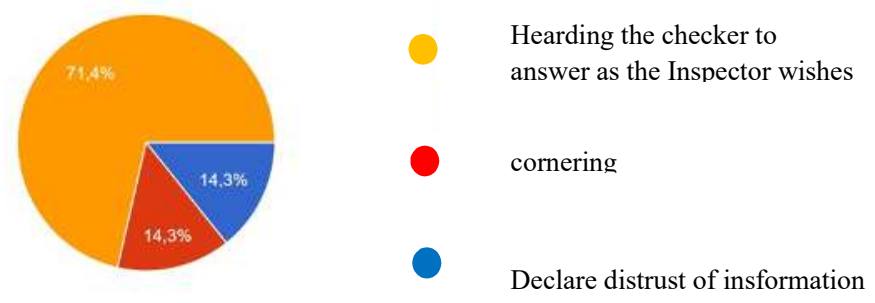

Based on Article 117 paragraph (2) of the Criminal Procedure Code affirms "In the event that the suspect gives information about what he has actually done in connection with the criminal offense against him, the investigator records in the minutes as accurately as the word used by the suspect himself." Authoritative text It implies that the Investigator is not allowed to control a single meaning based solely on authority-based single meaning, because, the answers of the Examiner cannot be reinterpreted and converted in writing based on the Investigator's own understanding.

Investigators place themselves as one of the binary opposition that dominates in the event of speech acts, not only by controlling the meaning of the various questions posed, but also raising reactions in negative emotive attitudes. As We question some Advocate colleagues through the Google Form Application with the problem "Have you ever gotten a way of the Examiner in asking questions accompanied by an intonation change, which makes your Client fear/stress?", Then some results answer (1) Yes, ever 71.4\%); and (2) Never $(28.6 \%)$. As described in the diagram below: 


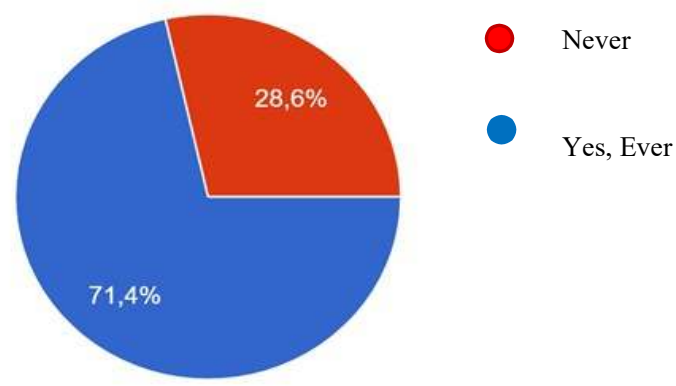

In fact, the model of communication between the Investigator and the examinee especially the Suspect, often continues outside the formal inspection process without being known by their Legal Counsel. This was described in the questionnaire through the Google Form application, which was filled by several Advocates, where as many as $92.9 \%$ stated that they had known of communication without the presence of a Legal Counsel.

The phenomenon of dominance in binary opposition is the intersection between controlling a single meaning - both based on presuppositions and institutional culture, with the ability to control emotions manifested in speech acts. Such a communication model is a violation of the Free of Pressure Principle normalized in Article 117 paragraph (1) of the Criminal Procedure Code which confirms that "the information of the suspect and or witness to the investigator is given without pressure from anyone and or in any form.

Saussure states that our knowledge of the world is mixed and determined randomly by the language that represents that knowledge. These meanings are bound in a system of relationships and differences that continuously determine our thinking and sensing. The complexity of the system of rules and transformation which underlies a person's grammatical speech does not mean the underlying expression - aware of the system that exists there is a speaker. According to Chomsky, who explained about 'Linguistic Competence', it was utterly unconscious, except when it was shown openly by the activities of advanced linguists (Norris, 2016). According to Raymond Geuss (2004), this will be verbally denied because these things enter unconsciously into them.

The dominant position is not only for someone who is examined by the Investigator but also for the Advocate as his Legal Attorney. As stated by IKS Advocates (April 15, 2019), Lawyers are often asked to be calm and are frequently asked to leave the examination location. The phenomenon of the expulsion of advocates in carrying out their functions and duties in assisting Clients, normatively juridically, cannot be considered as a violation of the law from the Investigator. Therefore, based on Article 115 paragraph (1) of the Criminal Procedure Code affirms "In the event that the investigator conducts an examination of the suspect, the legal counsel can follow the examination by seeing and hearing the examination." This means that the advocacy function of the Advocate is passive.

In the end, the Investigator, through the process of interpreting or evaluating the protests submitted by the Advocate, is seen as a disruption to the course of the investigation. This should be construed as an effort to maintain the consistency of the objectives of the Investigator in obtaining information based on pre-presumption and controlling the single meaning in speech acts to arrive at a conclusion regarding the occurrence of a crime and someone as a suspect.

The phenomenon as mentioned earlier, basically, also occurs in other parts of the world as explained by Joel Cohen (2010) who told that, in practice, prosecutors and judges 
sometimes persuade or even threaten suspects or defendants directly. Or even if not directly, the matter of persuasion or threat is carried out carefully through the intermediary of the lawyers or attorneys of the suspect or defendant. The substance of the persuasion or threat remains the same, namely to urge the suspect or defendant to admit his mistake, and if not, then a severe sentence will be imposed on him. And at least specifically for public prosecutors, on the one hand, they have an interest in enforcing formal procedural law, prosecution, and punishment under legal procedures. However, on the other hand, the fact is that the public prosecutor also put pressure on the suspect or defendant to confess, where it was, by the United States Supreme Court in 1978, considered not an error, even allowed (Cohen, 2010).

Starting from authoritative texts in Article 103 KUHAP in conjunction with Article 117 of the Criminal Procedure Code and communication behaviors in criminal justice practices as contained in the primary data, we do not intend to eliminate Derrida's phrase where writing is the main thing - the utterances (speech), in make interpretations in order to reveal the marginalized meaning. But in this case, Derrida seems to forget that Investigators as speakers are authority-based attribution holders to control the meaning of the authoritative text. So, it can also be said here that the authorities form a knowledge-based interest. The study of the emergence of 'interests' in knowledge has been going on for hundreds of centuries ago. This view was criticized by Habermas, who explained that in terms of the power of self-reflection, knowledge and interests are one (Hardiman, 2009). And it turns out, not only according to Habermas's interests, including the desires, needs, desires, and preferences (Geuss, 2004).

So it is interesting to examine deeper the causes of instrumental actions with the logic of the monologue of the Police Investigators in speech acts with Witnesses and suspects in criminal case examinations in the pre-adjudication domain. According to Barda Nawawi Arief (2011), it is indirectly interpreted as such, that the Criminal Law policy mostly contains policies governing/allocating and limiting power, both the power/authority of the citizens in general, namely to act/behave in community relations and power or authorities/law enforcement authorities. Judging from the aspect of criminal law policy, the fundamental problem of criminal law lies outside the field of criminal act itself, namely in the area of Constitutional Law.

Of course, we cannot directly legitimize this view. However, it should be noted the views of SF. Marbun (2001) states that concerning state activities there is a clear need for organizing the fields of government that carry out the tasks and functions of state administration which in daily practice requires an extensive organizing system, due to direct contact with the needs of the wider community. In achieving the goals of state life, it must involve the field of state administration in carrying out its very complex public service tasks, broad scope, and entering all sectors of life. The area of state administration has the freedom to determine policies even though the attitude of its actions must be accountable both morally and legally.

The study relating to the implementation of the function of the government - which is often assumed by the Criminal Law academics, is related to the management of state finances (budgeting) which is the primary driver of the functioning of the government. Moving on from this understanding, the examination process in the context of investigation also requires a good budgeting system. This can be seen in the Appendix of the Head of the Indonesian National Police Regulation Number 18 of 2012 concerning the Preparation of Key Indicators in the Indonesian National Police which emphasizes "In the framework of Good Governance development, the government's general policy is to run a results-oriented Government. As a result, the National Police in the context of investigation must set targets, so that the achievement of these targets will succeed when supported by a budgeting ceiling system. 
The success of development based on results is the premise that contains the existence of pragmatism contamination in the pattern of performance of the National Police. Thus, every performance pattern of the Police Investigator is interpreted as a way to achieve results. The meaning of 'criminal procedure law' is to focus on 'how to' and not on attaining 'results' only. Appendix of Regulation of the Chief of Police No. 18/2012 then emphasized "Outputs and results should be seen as performance, not the ability to absorb the budget because perceptions existed so far." performance, no money. "

Based on the description above, then the meaning that appears in the statement "... running a results-oriented government" implies neglecting the "how to" method. So, even though there is a statement "... not the ability to absorb the budget like the perception that has been used" which is used to break down the performance that has been used, but if the statement is associated with "institutional legal culture" for the inquisatoir principle to pursue recognition from Suspects, the monologue communication model will always occur. Therefore, the statement "Money follows function, ..." actually encourages a monologue communication pattern with an objective-instrumental model in the criminal case audit process.

In the end, the psychological impact of monologue communication, which arises in the Suspect and the Witness, is not the main problem in the criminal case examination process. Therefore, the main target is how to get information based on the interests of the Police Investigator. Although the Criminal Procedure Code provides a philosophical basis starting from respect for human rights, the formulations of authoritative texts are seen based on the traditional paradigm of thinking.

It is impossible to deny - even by the Investigator himself, that language will always be associated with the realization of communication. In the legal system in Indonesia, which is hegemony and dominated by the civil law system, it has a unique characteristic that is administrative. Therefore, in seeking information material which is written in written form, namely the Minutes of Examination finds its articulation in speech acts or oral communication while oral communication is thrown in situations and conditions both externally and internally from the side of the Investigator itself, which is then internalized in the form of written questions.

Investigators try to control the communication model, which is influenced by 'institutional legal culture' or social context, presuppositions from Investigators and jargon (special terms) in Criminal Law. Regarding the presupposition, according to Sarma Panggabean and T. Silvana Sinar (2018), there are several presuppositions (underlying assumptions) contained in the Investigator's question to be confirmed to the examinee. Prepresumption is a concept, where Hans-Georg Gadamer (2006) explains "Thus it is quite right for the interpreter not to approach the text directly, relying solely on the fore-meaning at once available to him, but rather to examine explicitly the legitimacy, i.e. the origin validity, of the fore-menaing present within him." Pre-assumption is the basis of the interpreter as background knowledge (hindergrundwissen), which later becomes a problem is when 'background knowledge' intersects with legal culture, then transforms into 'history of influence' (wirkungsgeschichte) with a subjectivus genetivus model. Therefore, the language of speech (parole) manifests itself in the form of genetivous subjectivus communication, meaning that the investigator consciously follows and believes that such a communication model is an exact process.

As We have explained above, where Article 117 paragraph (1) and paragraph (2) of the Criminal Procedure Code is a distillation of the accusatoir principle as a general legal principle in carrying out examinations in the criminal justice process. Where the examination 
is carried out by looking at witnesses and suspects as subjects protected by law and respecting human rights, the model of communication carried out by such Investigators is an embodiment of the principle of Inquisatoir which was adopted in the period before the Criminal Procedure Code was promulgated. Where the process of examination in the realm of investigation has positioned witnesses and suspects as objects of examination.

Thus, the communication model that is created is the punching of everyone who is withdrawn as an examinee. Therefore, in the end, all communication models that arise through verbal discussion, in essence, are false speech acts. Where, as if what appears on the surface is the proper process. But basically, there is no rational dialogue in the investigation process, because binary opposition has been created, namely the Investigator as the subject and the person examined as an object. Controlling single meanings appears in questions that are designed in such a way as to lead to presuppositions that are present in reasoning and legal arguments from Investigators accompanied by affective communication attitudes based on power - and not authority. So, if the examination process in making a Minutes of Investigation in the investigation process is a research model based on specific methods, other human beings who are put as the examinee are, in essence, not equal subjects, but merely research objects.

According to Gjalt-Jorn Y. Peters, Robert AC Ruiter, and Gerjo Kok (2014) explained that one of the main reasons for the use of forms of "threatening communication" was to confront the threatened party with the consequences he would get when he behaved certainly. This is done as part of an effort to arouse specific emotions from those who are threatened, and it is expected that after the feeling arises, then the next goals can be achieved, namely first, with the communication of the threat, it is likely that the attention or focus of the individuals threatened will the threater. Then, in the person who is threatened, the urge to selfreflection will arise, and then, he will behave according to what the threatening subject wants; second, and is still a series of these first points, in an individual who is threatened there will be an increase in awareness or conviction to change his attitude. Recognition like this arises because in the mind of an individual who is bullied, after the goal of the first point is reached, developing calculations or considerations of risks that he might be willing to accept on the willingness of the threatening subject. If he obeys, he will get what, and vice versa, if he does not follow, he will have the same fate.

In connection with the issue of the use of threatening words and bullying brought up by public prosecutors in the process of criminal law cases in the United States. Gershman (2014) even concluded that threats and intimidation had been used in almost all stages in the series of criminal procedure processes. According to Gershman (2014), in practice, it is actually still not very clear whether the use of threats and bullying is something that can be legitimized or not, because in reality there are some forms of threats and intimidation that are actually still possible to be "allowed" or even "encouraged" "Its use by the court. Gersham (2014) then conveyed the conclusions in the form of mapping from the types of threats and bullying used in criminal procedure. First, there are at least models of threats and intimidation that are still "permitted" to use them, although ethically they are still questioning whether or not they can be used. For such a model, there are several conditions that must be met, among others, the existence of a "legal basis" for such acts of threats and bullying, the existence of good faith and confidence in the public prosecutor that in fact the suspect or defendant wants to admit the mistakes he really did voluntarily, and later, had the purpose of revealing the facts and actual evidence relevant to the completion of a criminal case; and second, according to Gershman (2014), is a model of threats and bullying that are both from a legal and ethical standpoint that is strictly prohibited. Included in these threats and intimidation, among other things, are forms 
of action by public prosecutors who have no legal basis at all, even contrary to the law, then actions that are personally motivated, including measures that intend to silence political opponents or certain parties who raise criticism.

The condition of the speech act between the Investigator and the examinee, eventually obtaining academic legitimacy, is considered a skill of the Investigator in conducting investigative interviews as a form of investigator's proficiency in leading investigators (Pangabean and Sinar: 2018), in the process of investigating criminal cases.

Such communication models are constructed based on the old paradigm, where the paradigm, according to Habermas, contains a specific understanding of subjectivity, namely the subject that recognizes and controls the object monologically. Thus, formulating laws that underlie human behavior and the mechanism of social life in a way that is done in the natural sciences. Where the science objectifies humans, takes the neutral object towards the object of research and, if necessary, manipulates the research object experimentally (Hardiman, 2009).

To understand the whole legal system, we borrow the term symphony from Saussure to understand the entire music synchronously in studying the language. Saussure explains that we must realize synchronously as a network of relationships between sound and meaning. So, it is not possible to be understood atomically or individually (Kaelan, 2009). In the context of Law, there is also a rhythmic view, as stated by E. Utrecht (1989) that among each of these legal regulations, there is a relationship. Legal regulation does not stand alone. Every legal regulation has its place in the legal field. This place is a particular place, and this is the result or consequence of the interdependence (interconnected) of each social phenomenon. Some statutory regulations that contain several similarities in the form of elements which are the same or aim to achieve a common object are a set of specific rules, known as "an internal interconnection" (innerlijke samenhang).

The above view, in essence, is a view popularized by Paul Scholten that law is an overall set of rules and authorities arranged logically - but constantly changing and never closed - in a particular society in a certain time (Sidharta, 2011). So, it can be said that the law is an open system. In connection with this description, Paul Scholten explained as an attempt to positively value the values contained in society, of course, it cannot only rest on juridical dogmatic views but also includes a functional view. That makes Paul Scholten reject the view of Hans Kelsen, according to Paul Scholten, positive materials are historically and socially determined. Therefore, the purity of the Law always contains something that is not pure from the material (Prasetyo, 2013).

Thus, where the meaning of these phrases implies that departing from the social symptoms that exist in human life, arises due to the existence of various regulations on certain social symptoms. Where the arrangements are, because they come from several social symptoms, it is very possible that these rules intersect. But the main problem is not just how to make an interpretation - which manifests itself into legal action, because of speech - which is also part of legal action, also influences the criminal justice process. In fact, it is not uncommon for an end to the criminal justice process - from investigation to court proceedings, to be dependent on verbal and non-verbal communication skills or speech acts, both based on practical interests and academic interests.

The difficulty in conducting this research, there are at least two things, first, lies in the existence of interests that hinder to obtain primary data. This interest arises from a rational relationship between Advocates as respondents and Investigators. Therefore, in criminal justice practices, a mutually beneficial relationship between Andvokat and the Investigator is highly guarded. The difficulties in this study also arise from the interests of people who have been witnesses and/or suspects, in terms of their fear of the impact of the confession given in 
writing; secondly, as explained by Saussure and E. Utrecht above, Legal Studies experienced a throwback (gowerfen-sein) in the logical atomistic paradigm and logical positivism so that it had a linear pattern of reasoning and argumentation in understanding social symptoms.

\section{Conclusions}

The examination process at the investigation level based on KUHAP, in essence, accommodates the accusatoir principle as a form of respect for Human Rights. However, the main problem in the process is that the authoritative texts that prioritize 'results' are correlated with the budgeting mechanism for implementing law enforcement functions. Thus, the communication model created in the investigation process prioritizes controlling meaning and unbalanced speech acts. Finally, creating a binary opposition between Investigators and those examined. Therefore, based on the primary data and secondary data above, then, in essence, Investigators in carrying out their functions are still based on the principle of inquisatoir which is to objectify someone during the investigation process.

Speech-language in the civil law legal system - especially in Indonesia, has become a marginalized binary opposition, due to the purification of the law, which is the influence of the atomistic logical paradigm and logical positivism. Thus, Investigators in carrying out law enforcement functions based on the authority of attribution of the Criminal Procedure Code, view the communication model in speech acts that objectify witnesses and suspects, is normal and natural. In fact, the accompaniment of witnesses 'and suspects' answers is an achievement, insofar as it conforms to prejudice or prejudice (vorurteil) which controls its meaning.

\section{Acknowledgments}

In doing this study, researchers received supports, such as information and fund, from several institutions. So, in this part of paper, researchers would like to thank The Dean of Faculty of Law Pancasila University, Mr, Jupri form Gorontalo as an interviewer, and persons who are willing to be interviewed by the researchers.

\section{References}

[1] Cohen, Joel. When Defendants are Threatened to Plead Guilty. New York Law Journal, 244(71) (2010).

[2] Gershman, Bennett L. Threats and Bullying by Prosecutors. Loyola University Chicago Law Journal, 46(327) (2014).

[3] Hestiyana. Tindak tutur Penyidik dalam Interogasi Kasus KDRT (Kekerasan dalam Rumah Tangga) di Polresta Banjarmasin. Kadera Bahasa, 9(1) (2017).

[4] Jeuland, Emmanuel \& Sotiropoulou, Anastasia. The Role of Communication in the French Judicial System. International Journal for Court Administration, 4(3) (2012).

[5] Peters, Gjalt-Jorn Y., Ruiter, Robert A. C. \& Kok, Gerjo. Threatening Communication: A Qualitative Study of Fear Appeal Effectiveness Beliefs among Intervention Developers, Policymakers, Politicians, Scientists, and Advertising Professionals. International Journal of Psychology, 49(2) (2014). 
[6] Shanty, Wika Yudha. Analisis Terhadap Fungsi Bahasa Indonesia Hukum dalam Mewujudkan Kepastian Hukum. Jurnal Cakrawala Hukum, 7(2) (2016).

[7] Ungkang, Marcelus. Dekonstruksi Jaques Derrida sebagai Strategi Pembacaan Teks Sastra. Jurnal Pendidikan Humaniora, 1(1) (2013).

[8] Arief, Barda Nawawi. Kapita Selekta Hukum Pidana tentang Sistem Peradilan Pidana Terpadu (Integrated Criminal Justice System). Semarang: UNDIP (2011).

[9] Gadamer, Hans-Georg. Truth and Method. London-New York, Continuum (2006).

[10] Geuss, Raymond. Ide Teori Kritis. Habermas dan Mazhab Frankfurt. Magelang: Panta Rhei Books (2004).

[11] Hardiman, F. Budi. Demokrasi Deliberatif: Menimbang 'Negara Hukum' dan 'Ruang Publik' dalam Teori Diskursus Jurgen Habermas. Yogyakarta: Kanisius (2009).

[12] . Seni Memahami: Hermeneutik dari Schleiermacher sampai Derrida. Yogykarta: Kanisius (2015).

[13] . Kritik Ideologi. Menyingkap Pertautan Pengetahuan dan Kepentingan Bersama Jurgen Habermas. Yogyakarta: Kanisius (2009).

[14] Kaelan. Filsafat Bahasa, Semiotika dan Hermeneutika. Yogyakarta: Paradigma (2009).

[15] Marbun, SF., et al. Dimensi-Dimensi Pemikiran Hukum Administrasi Negara. Yogyakarta: UII Press (2001).

[16] Mertokusumo, Sudikno. Sejarah Peradilan dan Perundang-Undangannya di Indonesia Sejak 1942 dan Apakah Kemanfaatannya bagi Kita Bangsa Indonesia. Yogyakarta: Universitas Atma Jaya (2011).

[17] Norris, Christopher. Membongkar Teori Dekonstruksi Jacques Derrida. Yogyakarta: Ar-Ruzz Media (2016).

[18] Praja, Juhaya S. Teori Hukum dan Aplikasinya. Bandung: Pustaka Setia (2011).

[19] Prasetyo, Teguh. Kriminalisasi dalam Hukum Pidana, Bandung: Nusa Media (2013).

[20] Saleh, Roeslan. Mengadili sebagai Pergulatan Kemanusiaan. Jakarta: Aksara Baru (1983).

[21] Sidharta, Bernard Arief. Struktur Ilmu Hukum. Bandung: Alumni (2011).

[22] Soekanto, Soerjono, \& Sri Mamudji. Penelitian Hukum Normatif. Jakarta: Rajawali (1986).

[23] Susanto, F. Anthon. Dekonstruksi Hukum: Eksplorasi Teks dan Model Pembacaan. Yogyakarta: Genta Publishing (2010).

[24] Utrecht, E., \& Djindang, Moh. Saleh. Pengantar dalam Hukum Indonesia. Jakarta: Pustaka Sinar Harapan (1989).

[25] West, Richard, \& Turner, Lynn H. Introduction Communication Theory: Analysis and Application, Jakarta: Salemba Humanika (2008).

[26] Arifianti, Ika. Tindak Tutur Penyidik dalam Interogasi pada Kasus Delik Aduan di POLDA Jateng. Prosiding Seminar Tahunan Linguistik 2016, Program Studi Linguistik Sekolah Pascasarjana UPI, Masyarakat Linguistik Indonesia Cabang UPI, and Fakultas Pendidikan Bahasa dan Seni UPI (2016).

[27] Hutahaean, Erik Saut H. Psikologi Kepolisian: Seragam, Pangkat dan Senjata Api. Prosiding PESAT, 6 (2015).

[28] Panggabean, Sarma \& Sinar, T. Silvana. Praanggapan Penyidik dalam Interviu Investigatif (Kajian Linguistik Forensik dalam Penyusunan Berita Acara Pemeriksaan). The $11^{\text {th }}$ International Workshop and Conference of ASEAN Studies in Linguistics, Islamic and Arabic Education, Social Science and Educational Technology (2018).

[29] Satria, Robby. Analisis Kasus Pembunuhan dan Pemerasan Menggunakan Teori Linguistik NonKepengarangan: Sebuah Kajian Linguistik Forensik. Prosiding $1^{\text {th }}$ Celscitech-UMRI, 1 (2016).

[30] Waljinah, Sri. Linguistik Forensik Interogasi: Kajian Makna Simbolik Bahasa Hukum pada Tindakan Diskresi Polisi. Prosiding Konferensi Nasional ke-4, Asosiasi Program Pascasarjana Perguruan Tinggi Muhammadiyah (2016). 